\title{
CHANGES IN BIOCHEMICAL BLOOD VALUES DURING COMPLEX TREATMENT OF RHINOSINUSITIS POLYPOSA PATIENTS
}

DOI: 10.36740/WLek202103128

\author{
Natalia V. Khobotova', Valeriia K. Mishchenko² \\ 'DEPARTMENT OF OTORHINOLARYNGOLOGY, SE" DNIPROPETROVSK MEDICAL ACADEMY OF HEALTH MINISTRY OF UKRAINE", DNIPRO, UKRAINE \\ 2KHARKIV MEDICAL ACADEMY OF POSTGRADUATE EDUCATION, KHARKIV, UKRAINE
}

\begin{abstract}
The aim: To increase the effectiveness of treatment of sinusitis polyposa patients, develop and introduce a new non-traditional complex method of influencing several links of the pathogenesis of this disease, including laser therapy and laser puncture, used in the postoperative period.

Materials and methods: In 60 rhinosinusitis polyposa patients the indicators of lipid peroxidation and the state of antioxidant protection were studied. Depending on the type of treatment, the patients were divided into two groups: the first included 30 people who underwent traditional surgical intervention, and the second - 30 people who used complex therapy, including in the postoperative period endonasal laser exposure and laser puncture.

Methods: clinical data, the functional state of the nasal mucosa, indicators of lipid peroxidation (hydroperoxide, malondialdehyde) and antioxidant activity (glutathione peroxidase, glutathione reductase, reduced glutathione, superoxide cismutase, catalase) of erythrocyte membranes and blood serum were studied.

Results: The proposed complex method for treating lipids of erythrocyte membranes and serum, which includes endonasal surgical intervention, endonasal laser therapy and laser puncture leads to the normalization of physiological functions of the nose, activates antioxidant protection and reduces the peroxide activity of lipids in the membranes of erythrocytes and blood serum.

Conclusions: When examining patients in the long-term (after 1 year) period, a significant improvement in $85.7 \%$ of cases, an improvement in $10.7 \%$, and absence of effect in $3.6 \%$ was achieved. Thus, the proposed method of therapy can be recommended for widespread use in medical institutions.
\end{abstract}

KEY WORDS: Treatment method, rhinosinusitis polyposa

Wiad Lek. 2021;74(3 p.l):535-538

\section{INTRODUCTION}

Among the urgent problems of modern practical otorhinolaryngology, the issues of increasing the efficiency of diagnosis and treatment of inflammatory diseases of the nose and paranasal sinuses occupy one of the leading positions [1].

In recent years, there has been a significant increase in the number of diseases of the nose and paranasal sinuses both in absolute figures and in percentage of the total number of ENT diseases [2,3]. The increasing number of patients with inflammatory diseases of the paranasal sinuses causes significant expenditures in the public health system associated with modern technologies of treatment, as well as using a large number of expensive drugs $[2,4]$.

Chronic rhino-sinusitis polyposa accounts for $13 \%$ of all diseases of the nasal cavity and paranasal sinuses, and this indicator tends to further increase $[5 ; 6]$. The actuality of this issue is due to the increase of incidence of chronic polypous rhino-sinusitis and frequent recurrence of the process, in addition, the lack of clarity of many elements of pathogenesis. Polypoid rhino-sinusitis contributes to severe lower respiratory tract pathology such as pre-asthma and bronchial asthma, and can lead to life-threatening intraocular and intracranial complication.
When nasal breathing is impaired, the physiological functions of the nose change, leading to a weakening of ventilation capacity, gas exchange in the lungs, the development of hypoxia and hypercapnia [7].

Sinusitis polyposa is characterized by a prolonged course, frequent relapses. In this case, both local changes in the mucous membrane of the nasal cavity and paranasal sinuses are observed, as well as metabolic disorders, immunological reactivity, impairment of function of the endocrine and non-vascular system [8 - 11].

A large percentage of relapses of chronic sinusitis polyposa after surgery cause the search for and development of new treatment methods.

Medical methods of therapy for chronic sinusitis polyposa, prescribed after surgical treatment, are in most cases not effective and often intensify the manifestations of allergies, which worsens the course of the disease and contributes to an increase in relapses.

\section{THE AIM}

To increase the effectiveness of treatment of sinusitis polyposa patients to develop and introduce a new nonconventional complex method of influencing several links of the pathogenesis of this disease, including laser therapy and laser puncture used in the postoperative period. 


\section{MATERIALS AND METHODS}

Under the supervision there were 60 sinusitis polyposa patients, treated in the ENT clinic on the basis of the regional hospital named after I.I. Mechnikov. The control group included 34 clinically healthy individuals. Among the subjects, there were 36 men and 24 women aged 14 - 70 years. Methods: clinical data, the functional state of the nasal mucosa, indicators of lipid peroxidation (hydroperoxide, malondialdehyde) and antioxidant activity (glutathione peroxidase, glutathione reductase, reduced glutathione, superoxide cismutase, catalase) of erythrocyte membranes and blood serum were studied.

\section{RESULTS}

The effectiveness of therapy over time (before and 1,12 months after its completion), patients' clinical data, the functional state of the nasal mucosa, indicators of lipid peroxidation (hydroperoxide, malondialdehyde) and antioxidant activity (glutathione peroxidase, glutathione reductase, reduced glutathione, superoxide cismutase, catalase) of erythrocyte membranes and blood serum were studied.

The state of lipid peroxidation (LPO) processes was assessed by the level of hydroperoxides using a color reaction with ammonium thiocinate, by the accumulation of LPO secondary products, represented mainly by malonic dialdehyde and determined during the reaction with 2-thiobarbaturic acid, as well as by resistance of erythrocytes to peroxide effects based on the content of free hemoglobin, formed after hemolysis of red blood cells.

We studied the antioxidant defense system using the determination of SOD by the non-enzymatic method, as well as catalase - by the decrease in $\mathrm{H} 2 \mathrm{O} 2$, the activity of GLP, GLP and reduced glutathione in erythrocytes using standardized methods.

The diagnosis of sinusitis polyposa was established on the basis of patients' complaints, anamnesis, objective data, and the results of additional research methods: determination of the pathogenic microflora located on the nasal mucosa and radiography of the paranasal sinuses. Computed tomography was performed according to indications.

The leading complaint in $89 \%$ of the patients examined was difficulty or absence of nasal breathing and in $76 \%$ - disturbed olfaction in the form of hypo- or anosmia. Periodically attacks of rhinorrhea, paraxysmal sneezing occurred. General symptoms included headache, general weakness, decreased performance and disturbed sleep.

In anterior and posterior rhinoscopy, an edematous cyanotic mucous membrane, single or multiple polyps filling the nasal cavity were observed. In all clinical groups, significant impairments of the respiratory function, dynamic activity of the ciliated epithelium and the $\mathrm{pH}$ of the nasal secretion were revealed.

In sinusitis polyposa patients before treatment, activation of lipid peroxidation processes of erythrocyte membranes was found (an increase in the concentration of thiobarbituric acid hydroperoxide and malonic dialdehyde in erythrocytes and serum), as well as a decrease in antioxidant activity (AOA) in the initial stages of the disease due to glutathione enzyme system. Antioxidants still effectively inhibit the intensity of LPO processes, but the activity of the glutathione system is already decreasing. The activity of SOD remains unchanged or even increases due to pronounced compensatory and adaptive capabilities aimed at detoxifying LPO products and interrupting the processes of radical formation. With a disease duration of 10 years or more, LPO processes are significantly activated, which leads to a weakening of all links of antioxidant protection.

Depending on the type of treatment, the patients were divided into two groups: the first included 30 people who underwent the traditional surgical intervention and the second included 30 people who used complex therapy, including endonasal laser exposure and laser puncture in the postoperative period.

After traditional surgical treatment 1 month after in all the subjects of the first group nasal breathing, the dynamic activity of the ciliated epithelium and the $\mathrm{pH}$ of the nasal secretion were restored, the indicators of the patency of the nasal passages improved. Headache, disturbed sleep and other complaints disappeared in 16 (53.3\%) of them, anosmia persisted in $12(40 \%)$.

In rhinoscopy in 18 (60\%) individuals, the mucous membrane remained cyanotic or moderately edematous, scanty mucus discharge in the nasal cavity was noted and in $8(26.7 \%)$ individuals crusts were found.

In the study of LPO and AOA in the 1st group, there was a slight decrease in the level of hydroperoxide - by $1.1 \%$ compared to its indicators before treatment and the MDA content in the blood serum - by $3.7 \%$, and in erythrocytes - by $8.4 \%$; the antioxidant protection increased slightly: the concentration of reduced glutathione increased by $2.1 \%$, catalase - by $4.2 \%$, glutathione peroxidase - by $0.3 \%$, glutathione reductase - by $3 \%$, SOD - by $1.9 \%$ (Table I, II).

The effectiveness of therapy was assessed according to the criteria - "significant improvement", "improvement" and "no effect".

\section{DISCUSSION}

In the long-term period (1 year after), 28 individuals from the 1st group were examined. Significant improvement was noted in 14 (50\%) of them, improvement in 7 (25\%), no effect was observed in 7 (25\%).

Consequently, traditional surgical treatment was effective only in $53.6 \%$ of patients. Indicators of physiological functions of the nose, LPO, AOA, objective data after the operation did not change significantly.

In patients of the 2 nd group, on the next day after surgery, a session of local endonasal laser therapy was first performed in each half of the nasal cavity then a session of laser puncture performed daily. The course of treatment consisted of 8-10 sessions. The laser beam was supplied to the acupuncture points of the skin using a flexible light guide with special nozzles for focusing.

Biologically active points and points of general action (depending on the state of the body) segmentary connect- 
Table I. Indicators of lipid peroxidation of erythrocyte membranes and blood serum in sinusitis polyposa patients after conventional treatment

\begin{tabular}{|c|c|c|c|c|}
\hline \multirow{2}{*}{$\begin{array}{l}\text { Indicator, } \\
\text { unit of measure }\end{array}$} & \multirow{2}{*}{$\begin{array}{l}\text { Control } \\
(n-34)\end{array}$} & \multicolumn{2}{|c|}{ Patients } & \multirow{2}{*}{$\begin{array}{l}\text { Deviations of obtained } \\
\text { indicators in } \% \text { from their level } \\
\text { before treatment }\end{array}$} \\
\hline & & before & after treatment & \\
\hline Hydroperoxide, mol/l & 1,372 & 1,592 & 1,575 & $-1,1$ \\
\hline MDA in plasma, $\mathrm{mmol} / \mathrm{L}$ & 0,374 & 0,481 & 0,463 & $-3,7$ \\
\hline MDA in erythrocytes, $\mathrm{mmol} / \mathrm{L}$ & 7,406 & 8,693 & 7,962 & $-8,4$ \\
\hline
\end{tabular}

Table II. Indicators of antioxidant activity of erythrocyte membranes in sinusitis polyposa patients after conventional treatment

\begin{tabular}{|c|c|c|c|c|}
\hline \multirow{2}{*}{$\begin{array}{l}\text { Indicator, } \\
\text { unit of measure }\end{array}$} & \multirow{2}{*}{$\begin{array}{l}\text { Control } \\
(n-34)\end{array}$} & \multicolumn{2}{|c|}{ Patients } & \multirow{2}{*}{$\begin{array}{l}\text { Deviations of obtained } \\
\text { indicators in } \% \text { from their level } \\
\text { before treatment }\end{array}$} \\
\hline & & before & after treatment & \\
\hline Reduced glutathione, $\mathrm{mmol} / \mathrm{L}$ & 4,208 & 3,753 & 3,832 & 2,1 \\
\hline $\begin{array}{l}\text { Activity of glutathione-peroxidase, } \mathrm{mol} / \mathrm{l} \\
\text { Er. }\end{array}$ & 11,996 & 8,306 & 8,332 & 0,3 \\
\hline Activity of glutathione-reductase, mol. & 9,55 & 7,497 & 7,269 & 3 \\
\hline Catalase, mol/L.M. & 5,23 & 6,089 & 6,343 & 4,2 \\
\hline SOD, c.u. & 506,25 & 600,91 & 612,19 & 1,9 \\
\hline
\end{tabular}

Table III. Indicators of lipid peroxidation of erythrocyte membranes and blood serum in sinusitis polyposa patients after treatment with a complex method

\begin{tabular}{|c|c|c|c|c|}
\hline \multirow{2}{*}{$\begin{array}{l}\text { Indicator, } \\
\text { unit of measure }\end{array}$} & \multirow{2}{*}{$\begin{array}{c}\text { Control } \\
(n-34)\end{array}$} & \multicolumn{2}{|c|}{ Patients } & \multirow{2}{*}{$\begin{array}{l}\text { Deviations of obtained } \\
\text { indicators in } \% \text { from their level } \\
\text { before treatment }\end{array}$} \\
\hline & & before & after treatment & \\
\hline Hydroperoxide, mol/l & 1,372 & 1,592 & 1,367 & $-14,1$ \\
\hline MDA in plasma, $\mathrm{mmol} / \mathrm{L}$ & 0,374 & 0,481 & 0,44 & $-8,5$ \\
\hline MDA in erythrocytes, $\mathrm{mmol} / \mathrm{L}$ & 7,406 & 8,693 & 7,402 & $-14,9$ \\
\hline
\end{tabular}

Table IV. Indicators of antioxidant activity of erythrocyte membranes in sinusitis polyposa patients after treatment with a complex method

\begin{tabular}{|c|c|c|c|c|}
\hline \multirow{2}{*}{$\begin{array}{l}\text { Indicator, } \\
\text { unit of measure }\end{array}$} & \multirow{2}{*}{$\begin{array}{c}\text { Control } \\
(n-34)\end{array}$} & \multicolumn{2}{|c|}{ Patients } & \multirow{2}{*}{$\begin{array}{l}\text { Deviations of obtained } \\
\text { indicators in \% from their level } \\
\text { before treatment }\end{array}$} \\
\hline & & before & after treatment & \\
\hline Reduced glutathione, $\mathrm{mmol} / \mathrm{L}$ & 4,208 & 3,753 & 4,214 & 12,3 \\
\hline Activity of glutathione-peroxidase, mol/l Er. & 11,996 & 8,306 & 10,761 & 29,6 \\
\hline Activity of glutathione-reductase, mol. & 9,55 & 7,497 & 8,824 & 17,7 \\
\hline Catalase, mol/L.M. & 5,23 & 6,089 & 5,41 & $-11,2$ \\
\hline SOD, c.u. & 506,25 & 600,91 & 543,05 & $-9,2$ \\
\hline
\end{tabular}

ed with the respiratory organs were selected according to the rules for choosing acupuncture points [10; 13, 14-16]. In particular, the points of general action were used 014 (he-gu), 0111 (qui-chi), E36 (Tszu-san-li) and local - 0119 (he-liao), 0120 - (in-xiang), E3 - (ju-liao). In addition, the impact was also exerted on the extrameridianal points EM3 (yin-tang), EM15 (jia-bi).

Laser puncture always started with distant points of general action, which were changed daily to avoid adaptation.

One month after the treatment, nasal breathing was restored in all the patients of the 2 nd group, in $86.7 \%$ of patients olfaction improved, working efficiency increased, and sleep returned to normal.

On examination, none of them had polyps in the nasal cavity, the mucous membrane acquired a pink color in
93.3\% of cases, in $6.7 \%$ of cases its edema remained or it had a cyanotic hue.

The indicators of the main functions of the nasal mucosa returned to normal.

When studying the processes of LPO and AOA in individuals of this group, a significant decrease in the products of peroxidation was found. Their indicators approached the control values (the content of hydroperoxide decreased by $14.1 \%$, MDA in plasma - by $8.5 \%$, in erythrocytes - by $14.9 \%)$. An increase in the indicators of antioxidant protection was revealed, which approached the control values (the level of reduced glutathione increased by $12.3 \%$, glutathione peroxidase - by $29.3 \%$, glutathione reductase - by $17.7 \%$, and a decrease in the catalase content by $11,2 \%$, SOD - by $9.2 \%$ of their value before treatment (Table III. IV). 
In the long-term period ( 1 year after), 29 individuals were examined. A positive result of treatment, regarded as a "significant improvement" was established in 25 (85.7\%) of them, improvement - in $3(10.7 \%)$, no effect was noted - in $1(3.6 \%)$.

\section{CONCLUSIONS}

Thus, it can be stated that complex treatment with the use of endonasal laser therapy and laser acupuncture in the postoperative period is effective, significantly improves the general condition of patients, helps to restore nasal breathing, lengthening the period of remission. This complex method of treatment helps to normalize the impaired physiological functions of the nose, leads to a subsidence of inflammation in the mucous membrane of the nasal cavity and paranasal sinuses, activates antioxidant protection and decreases the peroxide activity of lipids in the membranes of erythrocytes and blood serum. The proposed method of therapy can be recommended for widespread use in medical institutions.

\section{REFERENCES}

1. Hong P., Pereyra C.A., Guo U., Breslin A., Melville L. Evaluating Complications of Chronic Sinusitis. Case Rep Emerg Med. 2017.8743828

2. Bergmark R.W., Pynnonen M. Diagnosis and First-Line Treatment of Chronic Sinusitis. JAMA.2017. Dec 19; 318 (23): 2344-2345.

3. Rosenfeld R.M., Piccirillo J.F., Chandrasekhar S. S., Brook I., Ashok Kumar K., Kramper M., Orlandi R.R., Palmer J.N., Patel Z.M., Peters A., Walsh S.A., Corrigan M.D. Clinical practice guideline (update): adult sinusitis. Otolaryngol Head Neck Surg. 2015. Apr; 152 (2): 1-39

4. Palamar B.I., Gruzieva T.S. The estimation of economic effectiveness of preventive measures of non-infectious diseases. «Wiadomości Lekarskie». 2019.72 (8): 1532-1541.

5. IskhakiYu.B. Allergy in otorhinolaryngology. Dushanbe:Irfon; 1980, p. 92.

6. Mikhireva M.M., Portenko G.M. Electropuncture in combination with surgical intervention in the treatment of patients with polyposis rhinosinusitis. Vestnik Otorinolaryngologii. 1990; 2: 40-45.

7. Dunaivitser B.I., Gyulkhasyan A.A., Minasyan 0.3. et al. On some neuroreflex reactions of the brain in patients with chronic paranasal sinuitis. Zhurn. ushnyh, nocovyh i gorlovyh boleznei. 1983; 3: 8-12.

8. Arefieva N.A., Bikbaeva A.I., Prozorovskaya K.N. Pathogenesis and treatment of patients with recurrent polyposis ethmoiditis. Zhurn. ushnyh, nocovyh i gorlovyh boleznei. 1991; 1: 14-20.

9. Lantsov A.A., Lavrenova G.V., ShlopovV.G., Shevchenko T.I. Morphological aspects of recurrent sinuitis. Zhurn. ushnyh, nocovyh i gorlovyh boleznei. 1991; 2: 38-41.
10. Skvirskaya I.V, Gicheva TN. The state of immune reactions in patients with chronic polypous rhinosinuitis. Materialy region. nauch.-prak. konf. Otorinolaringologov i rasshir Plenuma RNOL0; 20-21 June 1990, Irkutsk. M.; 1990, p. 46-47.

11. Filatov V.F., Zhuravlev A.S., Filatov S.V. Pathophysiological mechanisms of development and course of productive sinuitis. Neirogumoralnaya regulatsiya v patologi: Sb. nauchn.tr. Kharkov: KGMU; 1984, p. 123-127.

12. Lupir A.V. Clinical and epidemiological characteristics of the contingent of examined patients with polypoid rhinosinitis. Zhurnal ushnyh, nocovyh i gorlovyh boleznei. 2011; 5: 8-16.

13. Tabeeva D.M. Acupuncture guide. M .: Medicina; 1980.

14. Macheret E.L., Samasyuk I.Z. Reflexology Guide. K.: Visch. Shk., 1984.

15. Lopatin A.S. Modern theory of the pathogenesis of polyposis rhinosinusitis. Vestnik otorinolaringologii. 2003; 3: 110-114.

16. Mitin Yu.V., Shiyan S.P. Particularities of the pathogenesis and treatment of polypous rhinosinus. Zhurnal ushnyh, nocovyh i gorlovyh boleznei. 2012; 3: 152-153.

Research work of the department: "Development of new methods of diagnosis and treatment of diseases of the upper respiratory tract and ear". State registration number - 0118U006634. The term of execution - 2019 - 2022. Supervisor - prof. V.V.Bereznyuk.

\section{ORCID and contributionship:}

Natalia V. Khobotova: 0000-0003-3945-423X $X^{A, B, C, D, E, F}$

Valeriia K. Mishchenko: 0000-0002-8120-3568 ${ }^{B, D, F}$

\section{Conflict of interest:}

The Authors declare no conflict of interest

\section{CORRESPONDING AUTHOR Natalia V. Khobotova}

Department of Otorhinolaryngology,

SE "DMA of Health Ministry of Ukraine"

Soborna 14. Dnipro, Ukraine

tel: +380677857287

e-mail: Iornatalia1001@gmail.com

Received: 07.08 .2020

Accepted: 19.01.2021

A - Work concept and design, B - Data collection and analysis, C - Responsibility for statistical analysis,

$\mathbf{D}$-Writing the article, $\mathbf{E}-$ Critical review, $\mathbf{F}-$ Final approval of the article 